\title{
The effects of biliteracy instruction on morphological awareness
}

\author{
Roy Lyster, Jorge Quiroga and Susan Ballinger \\ McGill University
}

\begin{abstract}
This classroom intervention study investigated the effects of biliteracy instruction on Grade 2 students' morphological awareness in French and English. Three pairs of partner teachers (French/English) participating in a professional development project co-designed and implemented biliteracy tasks across their French and English classes, which together comprised a total of 80 students identified as dominant in either French or English or as French-English bilinguals. The biliteracy instruction integrated a linguistic focus on derivational morphology with a thematic focus on illustrated storybooks. Before and after the intervention, separate measures of morphological awareness in French and English were administered to a subsample of their students $(n=45)$ as well as to a comparison group of students $(n=20)$ not receiving the instruction. The experimental group significantly outperformed the comparison group in French, but not in English, yet when students' language dominance was accounted for in the English measure, English-dominant students in the experimental group significantly outperformed their counterparts in the comparison group.

French abstract at end.
\end{abstract}

Keywords: biliteracy instruction, morphological awareness, teacher collaboration, professional development, derivational morphology, phonological awareness, vocabulary development

This article reports on a quasi-experimental classroom study conducted as part of a larger professional development initiative, which involved a partnership with a local school board and aimed to facilitate collaboration between the French and English teachers of the same groups of students at the Grade 2 level. The participating school board, serving about 10,000 students across a large territory along the South Shore of Montreal, is officially designated as English-speaking. This designation allows it to provide schooling to students holding a certificate of eligibility for English education in Quebec: that is, students with at least one parent (or 
sibling) having attended an English school in Canada; all other children are required by law to attend schools designated as French-speaking. Although officially designated as an English-speaking school board, 38\% of its elementary students in 2005 claimed French as their home language, only 53\% claimed English, and 9\% claimed another language (Hobbs \& Nasso-Maselli, 2005). The high number of French-speaking children in an English-speaking school board is the result of cases where, even though French might be claimed as the home language, one parent (or sibling) had attended an English-speaking school in Canada and so the parents exercise their right to send their children to an English-speaking school. Their intention is to foster a degree of bilingualism in their children that would otherwise be difficult to attain in French-speaking schools where all subject matter - with the exception of English as a second language (L2) taught as a subject - is required by law to be taught exclusively in French, thereby prohibiting English immersion programs in schools designated as French-speaking.

To further set the scene for the study, this introduction will address (a) the issue of cross-linguistic pedagogy in biliteracy instruction, (b) the rationale for focusing on morphological awareness across languages, and (c) the preliminary research that led to the present study.

\section{Biliteracy instruction}

Previous research into literacy instruction in Canadian French immersion settings revealed a tendency for teachers - well in step with curricular objectives in content areas - to focus on vocabulary for the purpose of comprehension more than for drawing explicit attention to the formal and generative properties of words (Allen, Swain, Harley, \& Cummins, 1990). Results from this line of research included recommendations for explicit vocabulary instruction within communicative contexts that would employ cross-lingual teaching strategies and reference to cognates to alert students to differences and similarities between L1 and L2 (Allen et al., 1990; Clipperton, 1994; Harley \& King, 1989).

Others too have stressed the importance of cross-lingual connections, not only for vocabulary development but also for facilitating the role of the first language (L1) as a cognitive resource in L2 learning (e.g., Cook, 2001; Swain \& Lapkin, 2013). Cummins (2007) in particular has argued that, "learning efficiencies can be achieved if teachers explicitly draw students' attention to similarities and differences between their languages and reinforce effective learning strategies in a coordinated way across languages" (p. 233; see also Cenoz \& Gorter, 2011; SolteroGonzález, Escamilla, \& Hopewell, 2012). Drawing support from the notion that there is a common underlying proficiency that allows skills and concepts learned 
through one language to be transferred to another language, Cummins (2007) argues that cross-lingual instructional strategies would serve to subvert "the two solitudes assumption" (p.229) that has pervaded immersion programs and kept target languages separate, even though the goal is literacy in two languages (i.e., biliteracy).

But how can how teachers effectively encourage emergent bilinguals to draw on their knowledge of both languages while developing a sense of linguistic and contextual integrity for each language on its own? This is an important question for teachers to ask, because in school settings where competition for time and status between target languages may lead to the habitual use of one language over the other, the notion of each language having its own space becomes crucial.

The present study was designed to address this issue by focusing on teacher collaboration - that is, collaboration between teachers of different languages but of the same group of students (i.e., partner teachers). Partner teachers collaborated to co-design biliteracy tasks based on illustrated storybooks read aloud in both languages. By biliteracy tasks, we mean tasks that began in one language during its allotted class time and continued in the other language during its class time. The tasks were designed to draw attention to word formation and thereby develop students' awareness of derivational morphology within and across languages. In this way, each target language remained the language of communication in its respective classroom, even though borders between languages and classrooms were crossed during task completion.

\section{Morphological awareness}

The overall target of the intervention in the present study is morphological awareness, which entails "conscious awareness of the morphemic structure of words and ability to reflect on and manipulate that structure" (Carlisle, 1995, p. 194), and encompasses inflections, derivatives, and compounds (Kuo \& Anderson, 2006). The specific target of the present study is derivational morphology (involving affixes added to a base morpheme to change its meaning or syntactic category), which has been identified in previous research as problematic for immersion students (Harley, 1992; Harley \& King, 1989).

Immersion students' insufficient use of derivation in their L2 production has been explained in the light of the aforementioned observational research by Allen et al. (1990) that revealed considerable emphasis in immersion classrooms on learning the meaning of difficult words but with little attention drawn to the structural and generative properties of words. In contrast to such an approach, knowing a word is now considered to entail knowledge of not only its meaning but also 
its orthography, phonology, syntax, and grammatical function (Schmitt, 2008), as revealed by research on lexical development that advocates instructional approaches targeting "multiple aspects of L2 lexical knowledge" (Webb, 2005, p. 35). Specifically with respect to young learners, Cameron (2001) suggests shifting the focus of lexical instruction away from "just learning more words" and towards "expanding and deepening word knowledge" (p. 81); to do so, she further suggests instruction that exposes young learners to new words both in context and in isolation. To enable students to notice and retain vocabulary items more efficiently than encountering them only through reading for comprehension, Laufer (2003) recommends greater use of word-focused tasks.

Bowers, Kirby, and Deacon (2010) noted, however, that beyond immersion classrooms as well, "Typical classroom instruction includes very little, if any, systematic and sustained attention to the morphological structure of words" (p. 147). Yet there is convincing evidence that morphological instruction (a) improves reading comprehension (e.g., Carlisle, 2000; Kuo \& Anderson, 2006), (b) increases "motivation to investigate words" (Bowers et al., 2010, p. 145), and (c) develops vocabulary well beyond the words targeted by the instruction (Bowers \& Kirby, 2010). Bowers et al.s (2010) meta-analysis of 22 studies of morphological instruction from pre-K to Grade 8 revealed positive effects, especially for younger learners when the intervention was combined with other aspects of literacy instruction. Inspired by this meta-analysis, the present study draws on its results by implementing morphological instruction with 7-8-year-old children in the context of biliteracy units co-designed by their French and English teachers and based on the themes of illustrated storybooks.

It was initially thought that higher grades might be better suited to a focus on derivational morphology, in accordance with Kuo and Anderson's (2006) observation that children usually begin to develop explicit awareness of the structure and meaning of derived forms at around Grades 3 or 4, and Harley and Jean's (1999) recommendation for focused instruction on word analysis skills at around Grade 8. The decision to target students at the Grade 2 level in the present study was motivated by the school board's request for the research team to work with teachers at that grade level because teachers at higher grade levels were already engaged in other professional development activities. This created an opportunity for us to assess the feasibility and effectiveness of biliteracy instruction aiming to increase the morphological awareness of younger learners at emergent stages of literacy development. As Bowers et al. (2010) suggested, "If morphological instruction were introduced early in literacy learning, morphological knowledge would have time to become consolidated and have more opportunities to contribute to literacy learning" (p. 148).

Because the present study investigates the effects of integrating cross-linguistic pedagogy with biliteracy instruction on students' morphological awareness in 
English and French, it begs the question as to whether the effects will be similar in both languages. Specifically with respect to biliteracy development, Deacon, Wade-Woolley, and Kirby (2007), in a study of emergent French-English bilinguals in French immersion at the Grade 1-3 level, found "robust evidence of crosslinguistic transfer of morphological awareness" (p. 741) but also that the "crossover effect" entailed "developmental changes in the language source of the morphological awareness" (p. 744). That is, early morphological awareness in English contributed to reading in both English and French, whereas early morphological awareness in French contributed to reading only in French but then contributed to both languages later on. Similarly, in a study with young English-Chinese bilinguals in Grades 1 to 4, Pasquarella, Chen, Lam, and Luo (2011) found significant transfer effects for compound awareness from English to Chinese but not from Chinese to English, and attributed this finding to the fact that Chinese has a greater number of compounds than English. One of the issues motivating the present study, therefore, is whether biliteracy instruction focusing on derivational morphology in both English and French will have differential effects across languages.

\section{Background and research questions}

The present study was part of a professional development project, called Teacher Collaboration for Integrated Language Learning (TCILL) and funded by the Québec Ministère de l'Éducation, du Loisir et du Sport (MELS) to support a partnership between the researchers and the aforementioned school board. The goals of the two-year professional development initiative were (a) to create curricular coherence across French and English classes, (b) to facilitate collaboration between French and English teachers, and (c) to strengthen students' vocabulary knowledge in both languages. These goals were established in light of the social and linguistic demographics of the participating school board, which today hosts a blend of L1 and L2 learners in the same classrooms.

The initiative built on a previous study undertaken by Lyster, Collins, and Ballinger (2009) in collaboration with six teachers in the same school board. This previous research entailed the implementation of a Bilingual Read-Aloud Project whereby the French and English teachers of each class read aloud to their students from the same chapter books over four months, alternating the reading of one chapter in the French class with another in the English class. Students became enthusiastic participants during the reading of the stories in both languages, which appeared to enable the students, irrespective of language dominance, to understand the stories. Moreover, their interest in continuing to read stories on their own from the same book series was striking. During the read-aloud sessions, 
propitious opportunities arose for students to learn a new concept along with new words in both languages, yet systematic collaboration among teachers to make connections across languages was minimal. The researchers concluded that, to better exploit the potential that such a project has for facilitating teacher collaboration on language-based objectives, more time for participating teachers to actually collaborate on planning, as well as more structured guidance regarding the language focus, would be needed. This conclusion provided the impetus for the two-year TCILL project, which, thanks to the financial support of the MELS, allowed participating teachers to be released from their teaching duties in order to participate in a series of professional development workshops.

Both Years 1 and 2 of the TCILL project entailed similar professional development workshops, whereas Year 2, which is the focus of this article, included a set of pre- and post-intervention measures designed to address the following research questions:

1. Do children in Grade 2 benefit from biliteracy instruction targeting morphological awareness in the context of illustrated storybooks in both French and English?

2. Are the effects of instruction different across languages and influenced by the children's language dominance or program type?

\section{Method}

The present study reports on the results of Year 2 of the TCILL project because it was only during Year 2 that formal testing of students' morphological awareness was conducted. The results pertain specifically to four classes, comprising a total of 80 students, taught by three pairs of partner teachers participating in the TCILL project. The partner teachers co-designed and implemented biliteracy instruction integrating a linguistic focus on derivational morphology with a thematic focus on illustrated storybooks. Before and after the intervention, separate measures of morphological awareness, vocabulary size, and phonological awareness were administered in both French and English to a subsample of their students as well as to a comparison group of students not receiving the instruction.

\subsection{Participants}

Year 2 of the TCILL project began with a cohort of 10 teachers ( 8 females and 2 males), all with previous teaching experience, in addition to 3 lead teachers (all female) who, having participated in Year 1, agreed to play a mentoring role during 
Year 2. Other participants in the professional development activities during Year 2 included 3 researchers from the university (i.e., the authors) and the English and French language consultants (both female) from the school board. Of the teachers who participated throughout all of Year 2, only one had training in L2 education (i.e., a certificate in teaching French L2) while one other had completed a BA in Psychology and Linguistics prior to undertaking her B.Ed. in elementary education. All others had training in elementary education with no specialisation in either L2 teaching or linguistics.

Among the cohort of 10 teachers, the two males shared two classes in a 50/50 French/English bilingual program: a Grade 2 class $(n=23)$ and a Grade 2/3 class $(n=18)$. A second pair taught a Grade 2 class $(n=22)$ in a French immersion program with $80 \%$ of its curriculum in French and $20 \%$ in English. A third pair taught a Grade 2 class $(n=17)$ in an English stream program with $80 \%$ of its curriculum in English and 20\% in French. A fourth pair taught a Grade $2 / 3$ class $(n=18)$ also in an English stream program ( $80 \%$ English $+20 \%$ French) but the French teacher of this class had to withdraw from the project due to health reasons. The English teacher continued, collaborating with other participating teachers from her school, but her lessons were not video taped and her students' test results were not used in the analyses. A fifth pair taught a Grade 1 class $(n=16)$ in a French immersion program $(80 \%$ French $+20 \%$ English), but their students did not participate in the testing because our measures, described below, were designed specifically for Grade 2 students.

Participating teachers thus represented three different programs with different proportions of instructional time in the target languages: (a) 80\% French + 20\% English, (b) 50\% French $+50 \%$ English, and (c) 20\% French $+80 \%$ English. Although our initial intention was to work with the French and English teachers of French immersion students (in programs ranging from 50\% to $80 \%$ in French), the school board was keen on opening the project up to non-immersion programs as well. This allowed us to investigate the extent to which variable proportions of target languages across the curriculum might influence biliteracy instruction and its effects on student outcomes.

In addition to the teachers and students participating in the project's professional development component and thus as an experimental group, 20 students whose teachers were not participants in the TCILL project served as a comparison group by taking the same set of tests as students in the experimental group. These students were from two different schools in the same school board as the experimental students, one with an $80 \%$ English program $(n=10)$ and the other with an $80 \%$ French program $(n=10)$. No students in the comparison group were from a 50/50 bilingual program. However, with a mixture of English-dominant, Frenchdominant, and bilingual students, the language dominance of the 20 students in the comparison group reflected that of the experimental group. 
Table 1. Distribution of participants (experimental + comparison) by program type and language dominance

\begin{tabular}{lllll}
\hline & $\begin{array}{l}\mathbf{8 0} \text { French } \\
\text { program }\end{array}$ & $\begin{array}{l}\text { 50\% French } \\
\text { program }\end{array}$ & $\begin{array}{l}\text { 20\% French } \\
\text { program }\end{array}$ & total \\
\hline English-dominant students & $6+2$ & $3+0$ & $0+6$ & $9+8=17$ \\
French-dominant students & $1+4$ & $8+0$ & $7+1$ & $16+5=21$ \\
Bilingual students & $7+4$ & $10+0$ & $3+3$ & $20+7=27$ \\
total & $14+10=24$ & $21+0=21$ & $10+10=20$ & $45+20=65$ \\
\hline
\end{tabular}

In the case of both experimental and comparison groups, convenience sampling was the method used to recruit students for testing, with those having returned signed parental consent forms being selected $(n=78)$. Of the 58 students in the experimental group, 3 were in Grade 3 and so their data were not used in the final analyses; the 5 from the class whose French teacher was unable to implement the treatment were excluded and 5 others were excluded from the analyses because they did not complete all the tests. In total, therefore, results from 45 experimental students ( 23 girls, 22 boys) and 20 comparison students ( 7 girls, 13 boys) were included in the statistical analyses. The distribution of all 65 student participants according to treatment condition, program type, and language dominance (determined by a measure of receptive vocabulary size as explained later) appears in Table 1.

\subsection{Workshops}

Five daylong workshops were held for participating teachers at the school board office throughout Year 2. The first workshop (November 2011) began with an overview of the project that included videos from the Bilingual Read-Aloud Project (Lyster et al., 2009) as well as videos from Year 1, and then explored the use of illustrated storybooks for teaching language and enhancing biliteracy skills. The second workshop (December 2011) first addressed vocabulary instruction and teacher collaboration, and then gave teachers the opportunity to test the waters of collaboration as they worked together on designing tasks to accompany The Three Robbers (Ungerer, 1962/2008), which they had the option to then use with their students or not. The third and fourth sessions (February and March 2012) were devoted to collaboration between partner teachers who co-designed biliteracy tasks to accompany their reading aloud to students of Moon Man (Ungerer, 1967/2009) and Crictor (Ungerer, 1958), respectively. Following each of these sessions, the research team made visits to the schools to videotape the implementation of at least four lessons (two in each language) that the teachers had co-designed for 
each storybook. The fifth and final professional development session (June 2012) was structured around viewing the videotaped lessons, which served to initiate a stimulated-recall procedure that allowed teachers to discuss their mutual implementation of co-designed interventions as well as their students' involvement in both target languages.

\subsection{Instructional treatments}

The instructional treatments drew on the components of a counterbalanced approach that integrates form-focused and content-based instruction in ways that encourage shifts in students' attention between language and content (Lyster, 2007). While the language focus was on derivational morphology, the content focus emerged from the themes of illustrated storybooks, which proved to be a rich source of both language and content for young learners of different proficiency levels and program types.

The instructional interventions, which lasted an average of roughly 8-10 hours (4-5 hours each for Moon Man and Crictor), were not expected to be completely identical across classrooms. This is because the professional development component emphasized collaboration between partner teachers, who were invited to draw on their own creativity to adapt the linguistic resources provided during the workshops to their respective teaching styles and students' needs. What remained constant across the interventions were the storybooks and their themes as well as the emphasis on derivational morphology as outlined in the materials provided to teachers during the workshops. In each language, teachers received a 4-page document for Moon Man and a 6-page document for Crictor suggesting various word-focused tasks. Prefixes appearing in these tasks included dis- and un- in English and dé-, in-, and mal-in French. Suffixes in English included -able, -al, -ible, -ful, -ic, -ity, -ness, -ous, -sion, and -tion, while those in French included -able, -al, -eur, -eux, -ible, -ier, -ique, -iste, -ment, -té, and -tion. The focus was thus on bound morphemes and more frequently on suffixes than on prefixes.

Whereas chapters had been read in alternation from one language to the next in the Bilingual Read-Aloud Project (Lyster et al., 2009), the illustrated storybooks used in the present study had no chapters. Consequently, some partner teachers read the storybooks at least once in each language while others opted to read short sections alternating between languages. In both cases, teachers drew attention to target words during their reading aloud and then followed up with scaffolding techniques or word games to focus on derivational morphology, as in the following example pertaining to Crictor.

Crictor is a pet boa constrictor who, after saving his owner from a burglar at the story's climax, is awarded a medal for his bravery and has a statue erected in his 
honour. To emphasize the theme of heroism during the reading aloud of the story, English teachers drew attention to key words such as helpful, faithful, honour, and respected, while French teachers highlighted their French equivalents: serviable, fidèle, honneur, and respecté. A typical follow-up word-focused task used by one of the English teachers engaged students in using prefixes (i.e., un- and dis-) to form antonyms (i.e., unhelpful, unfaithful, dishonour, disrespected) as they imagined alternative endings to the story. To further highlight derivational relationships in reference to Crictor's heroic traits, the words hero and heroism were emphasized in the English class and héros and hérosime in the French class. English teachers were encouraged to draw attention to the suffix -ic in heroic and to incite students to discover by analogy similar derivations (e.g., science $\Rightarrow$ scientific; history $\Rightarrow$ historic) while French teachers were encouraged to draw attention to the suffix -ique in héroïque and to incite students to discover analogous derivations in French (e.g., science $\Rightarrow$ scientifique; histoire $\Rightarrow$ historique). Still other word-focused tasks, when deemed appropriate and relevant by teachers for their students, targeted similar patterns of suffixation in words whose meanings were closely tied to the story (e.g., courage $\Rightarrow$ courageous or courageux; danger $\Rightarrow$ dangerous or dangerous).

To the extent possible, the instructional treatments were videotaped, yielding about 12.5 hours of video recorded lessons across four pairs of teachers and their five intact classes (including the two Grade 1 teachers). Scheduling even more class visits for videotaping proved challenging for the research team because the participating teachers implemented their lessons at roughly the same time. Consequently, to provide a more complete portrait of the instructional treatments, teachers submitted lesson plans and, during the final daylong meeting in June with colleagues, shared artefacts that they had created for use during their interventions or that students had produced as a result.

\subsection{Measures}

The present study employed three different measures, each intended to assess a specific language domain and relationships among them: (a) morphological awareness (b) receptive vocabulary size, and (c) phonological awareness. The tests were administered individually to students as a pre-test in January-February and as a post-test in May-June. Each measure had two versions, one in English and the other in French, which were administered at separate times. Research assistants conducted the testing one-on-one with individual students in a convenient and quiet location near the classroom. Testing time per student took an average of 50 to 65 minutes in each language and was distributed over four days at each school as follows: 
Day 1: Morphological Awareness Test in English

Day 2: Vocabulary and phonological awareness tests in English

Day 3: Morphological Awareness Test in French

Day 4: Vocabulary and phonological awareness tests in French

For all tests in both languages at both testing times, practice items were used to ensure that students understood the tasks before beginning the tests.

\subsubsection{Peabody Picture Vocabulary Test/Échelle de vocabulaire en images Peabody}

The Peabody Picture Vocabulary Test - Fourth Edition (PPVT-4; Dunn \& Dunn, 2007) and its French equivalent, Échelle de vocabulaire en images Peabody (EVIP; Dunn, Dunn, \& Thériault-Whalen, 1993), were used as standardized measures of receptive vocabulary for the purpose of identifying possible relationships between vocabulary size and our measure of morphological awareness and also for identifying students as English-dominant, French-dominant, or bilingual. During the test, which was administered individually and lasted an average of 20 minutes in each language, the researcher says a word orally and asks the child to point to the corresponding picture in a set of four pictures.

The pre-test scores obtained on the PPVT-4 and EVIP were used to determine individual students' dominant language because previous experience in our program of research suggested that reports of a child's home language - whether provided by the child, teacher, or parent - were unreliable indicators of the child's actual language dominance. Because the group means obtained on pretests were similar in both languages (97.0 in English and 98.5 in French), we used raw scores to calculate the difference for each individual between the English and French versions and then a percentage of how many more words were identified in one language than the other. What then proved most effective for forming three groups based on these percent differentials was to consider participants dominant in one language if they identified a minimum of $20 \%$ more words in that language than the other. Students classified as English-dominant $(n=17)$ identified an average of 58\% more words in English than in French, whereas students classified as French-dominant $(n=21)$ identified an average of 35\% more words in French than in English. Students classified as bilingual $(n=27)$ identified a similar proportion of words in both languages, with an average of only $1 \%$ more in one language than the other.

\subsubsection{Auditory Analysis Test/Test d'analyse auditive en français}

Rosner and Simon's (1971) Auditory Analysis Test (AAT) was used as a measure of phonological awareness, along with its French counterpart, Test d'analyse auditive 
en français (TAAF: Cormier, Grandmaison, MacDonald, \& Ouellette-Lebel, 1995), for the purpose of identifying possible relationships between phonological awareness and our measure of morphological awareness. The phonological tests, each of which took 10-15 minutes to complete, required the child first to repeat a given word (40 items in English and 42 in French) and then to say it again without pronouncing a specific phoneme, cluster, or syllable. For example, in the English version, a child is asked to repeat the word swing then to say it again without the sound /w/. In the French test, children were asked, for example, to repeat the word brise then to say it again without the sound $/ \mathrm{r} /$.

\subsubsection{Morphological Awareness Test (MAT)}

Two versions of a 40-item Morphological Awareness Test (MAT) - one in English and the other in French - were developed and validated specifically to serve as this study's primary measure for assessing the effects of the biliteracy instruction. Individual students completed the 40 items during an average time of 20-30 minutes (for each language) by interacting with a researcher orally while having visual access to the items appearing on a test sheet. Both versions included a balance of familiar and unfamiliar items insofar as about half had appeared in the wordfocused tasks provided to teachers during the workshops and half had not. In line with the instruction, more test items involved suffixation than prefixation.

The first set of 20 items assessed morphological awareness through processes of analysis (i.e., decomposition) by requiring students to separate a derived form into its morphemic constituents (Appendix A). Students were told that, to complete the task, they had to divide a given word into "a main word and one or two parts" as in the following example: "ADMIRABLE; the main word is ADMIRE and the extra part is ABLE." To practice, students were given the word usefulness, and were expected to identify use as the main word, and ful and ness as the two extra parts. These items were scored according to a weighted scoring model that attributed: (a) 2 points if the student correctly identified the base and 1 point if the student identified a smaller word in the larger one but not the exact base; (b) 1 point for each affix identified by the student (some items had two affixes and others only one); (c) 1 point if the student identified the constituent parts in the right order. Top score was 5 for 6 of the items (e.g., uncomfortable $=u n+$ comfort + able) and 4 for 14 of the items (foolish $=$ fool $+i s h$ ), for a total of 86 possible points on this section.

The second set of 20 items assessed morphological awareness through processes of synthesis (i.e., derivation) by requiring a student to employ knowledge of suffixation to produce a derived form from its base (Appendix B). As an example, students heard and saw the sentence, "When we PRODUCE something in our classroom, that thing is our PRODUCTION." Students were asked to complete 
sentences orally by creating a new word using all or part of a given base and adding "a few extra letters" at the beginning or end of the base. For practice, students heard and saw the sentence, "If you live in PEACE, you are very

and were expected to produce the derived word peaceful. These items too were scored according to a weighted scoring model that attributed: (a) 0 points if the student created a compound word or used either no suffix or one resulting in the wrong syntactic category (e.g., adding -ing to create a verb when the context required a noun); (b) 1 point if the student created a word within the right syntactic category but with a non-idiomatic suffix in the wrong sub-category (e.g., creating an abstract noun in contexts requiring a concrete noun, such as feuillition instead of feuillage); (c) 2 points if the student created a word with the wrong suffix, but in the right category and the right sub-category (as in stupidness where the suffix denotes a state of being in the same way as the more idiomatic suffix -ity); (d) 3 points for the right derived form. Top score for each item was 3, for a total of 60 possible points in this section. The maximum number of points a student could achieve on either version of the MAT, therefore, was 146.

Each version of the MAT was scored by two coders: a native speaker and a near-native speaker of English each scored all the English tests while a native speaker and a near-native speaker of French each scored all the French tests. Prior to scoring, there were two training sessions. The first was conducted on an individual basis with each coder and the second was held with both coders together for one language, scoring sample items and discussing questions. The degree of consistency between both coders was calculated using the Pearson correlation coefficient; the significant correlations revealed very high inter-rater reliability for both the English MAT $(r=.993, p<.001)$ and the French MAT $(r=.999, p<.001)$.

Each version of the 40-item MAT included 10 items borrowed from oft-cited tests of morphological awareness: 10 in English from Carlisle (2000) and 10 in French from Casalis and Louis-Alexandre (2000). The development of the other 30 items on each test was informed by the construct of word frequency (Nation, 2001; Bauer \& Nation, 1993; Coxhead, 1998, 2000; Cobb \& Horst, 2004) as a way of ensuring increasing levels of difficulty. In the case of the English MAT, the 2000 most frequent words comprising West's (1953) General Service List were analyzed using the VocabProfile application in the Compleat Lexical Tutor (Cobb, n.d.) to identify base words that would change from a high-frequency ranking to a lowerfrequency ranking when different affixes from Nation's (2001) sequenced list of derivational affixes were added. For example, the base personal appears among the 2000 most frequent words identified in the General Service List whereas its derived forms personality and personalize do not; personality is among the 3000 most frequent words of the British National Corpus (2001) whereas personalize is among the most frequent 6000 words in that same corpus. For this reason, the 
more frequent word personality was thought to pose less of a challenge for a student to decompose or derive from the word personal than having to do the same operations for the less frequent word personalize.

Similar steps were taken to design the French version with increasing levels of difficulty, although the resources we had at our disposal regarding the frequency of words and derivational affixes in French were not as extensive as those in English. We drew on the work of Vander (1932) as well as Gougenheim's (1958) list of the 3000 most commonly used words in French. Decisions about which affixes to use in the French MAT were informed mainly by Retman (1980) and Dubois (1962). The final list of French words was subjected to a simple frequency analysis by the VocabProfil application in the Compleat Lexical Tutor (Cobb, n.d.).

The analysis of the internal consistency of the MAT using pre-test scores yielded high levels of test reliability for both versions: Cronbach's $\alpha=.81$ for the English version and .88 for the French version. In addition, also using pretest scores, within-subject ANOVAs were conducted to determine whether there were indeed increasing levels of difficulty (i.e., easy, intermediate, difficult) within each section (analysis and synthesis) on both versions. The results confirmed the intended gradation of difficulty within each section of both MAT tests, with the exception of an overlap between intermediate and difficult items in the synthesis task on the French MAT.

We now describe additional means we adopted to validate both versions of the MAT; the full analysis appears in Quiroga (2013). First, each version of the 40-item MAT included 30 items that we created as well as 10 items borrowed from oft-cited tests of morphological awareness; this allowed us to conduct a correlational analysis to test for convergent validity. The results showed that the 30 items we developed for each test had a significant correlation with the 10 borrowed items, both on the English MAT, $r=.58, p<.001$, and the French MAT, $r=.80$, $p<.001$. Second, because morphological awareness is bidirectionally correlated with vocabulary size (Carlisle, 2000; Kuo \& Anderson, 2006) and also thought to correlate with phonological awareness (McBride-Chang, Wagner, Muse, Chow, \& Shu, 2005), we conducted a set of correlational analyses on the pretest scores of these measures in each language.

The results of the correlational analyses of the English measures indicated a medium and significant correlation between morphological awareness and vocabulary size, $r=.68, p<.001$, and a positive but weak correlation between morphological awareness and phonological awareness in English, $r=.18, p=.12$. Similarly, the results of the correlational analysis of the French measures indicated a strong and significant correlation between morphological awareness and vocabulary size, $r=.70, p<.001$, and a positive but weak correlation between morphological awareness and phonological awareness, $r=.20, p=.056$. 
In sum, analyses of pretest scores indicate that both versions of the MAT are valid measures of morphological awareness as shown by the significant correlations between our items and those borrowed from previous studies and also by their correlations with measures of vocabulary size. Both versions of the MAT can thus be said to measure a construct that is (a) similar to what previous measures of morphological awareness have tapped into and (b) related to vocabulary size but distinct from phonological awareness. Finally, the coefficients of internal consistency and coding consistency indicate that the English and French versions of the MAT are both reliable measures of morphological awareness.

\subsection{Teacher interviews and questionnaire}

Pairs of participating teachers were interviewed in December and then again in June. The first interview served to ascertain their linguistic and educational backgrounds, their previous collaboration experiences with colleagues, their approach to vocabulary instruction, and their reasons for participating in the project. The second interview served to capture their impressions of the collaborative process and the professional development component of the project, the storybooks used, and their students' reactions to the biliteracy intervention. At the same time, in June, teachers were asked to complete a questionnaire, also eliciting their impressions of the feasibility of collaboration with their colleague and their perceptions of its effects on their students.

\section{Results}

\subsection{Morphological Awareness Test (MAT)}

Analysis of covariance (ANCOVA) was used to examine the effects of biliteracy instruction with a cross-lingual focus on derivational morphology (i.e., the main factor with two levels: experimental group and comparison group) on post-test scores (the dependent variable) of the English and French versions of the MAT. ANCOVA is considered ideal for quasi-experimental studies, such as this one, in which participants cannot be assigned randomly to experimental and comparison groups. ANCOVA generates between-group comparisons of post-test means that have been adjusted relative to the pre-test means in order to factor out the effects of initial between-group differences. The one-way ANCOVA used in the present study controlled not only for initial group differences by using MAT pre-test scores as a covariate, but also for phonological awareness by using AAT and TAAF post-test scores as covariates in the model. The procedure outlined next confirmed 
that the assumptions for ANCOVA were met and also that there was no interaction effect between group and pre-test scores.

The assumption of homogeneity of linearity for the ANCOVA model was checked by introducing and testing an interaction effect between group and pretest scores. Analysis of residuals was used to explore the assumptions of normality and equal variances of errors, as well as the presence of possible outliers. As a result, one participant was identified as an outlier based on an unually high post-test score (142/146) on the English MAT and was excluded from the analyses of this measure. Pair-wise comparisons, where warranted, were conducted, and $p$ values were adjusted for multiple testing with the Tukey-Kramer method. The statistical analyses were carried out with SAS software, version 9.2. All hypothesis tests were two-sided and performed at the 0.05 significance level.

\subsubsection{Overall group analysis}

Figure 1 displays the unadjusted means obtained at both testing times by each group on the English and French versions of the MAT. Table 2 displays the descriptive statistics for each version by group as well as the adjusted post-test means resulting from the ANCOVA.

A one-way ANCOVA of the English MAT post-test scores revealed no significant differences between groups, $F(1,60)=0.15, p=0.70$, although phonological awareness proved to have a significant effect, $F(1,60)=10.45, p=0.002$. A oneway ANCOVA of the French MAT post-test scores showed that the experimental group significantly outperformed the comparison group at the time of post-testing, $F(1,61)=12.15, p<0.001$, with an adjusted mean difference of 10.88 (95\% CI $[4.64,17.12])$. Unlike the English MAT results, phonological awareness was not significant, $F(1,61)=3.54, p=0.06$.

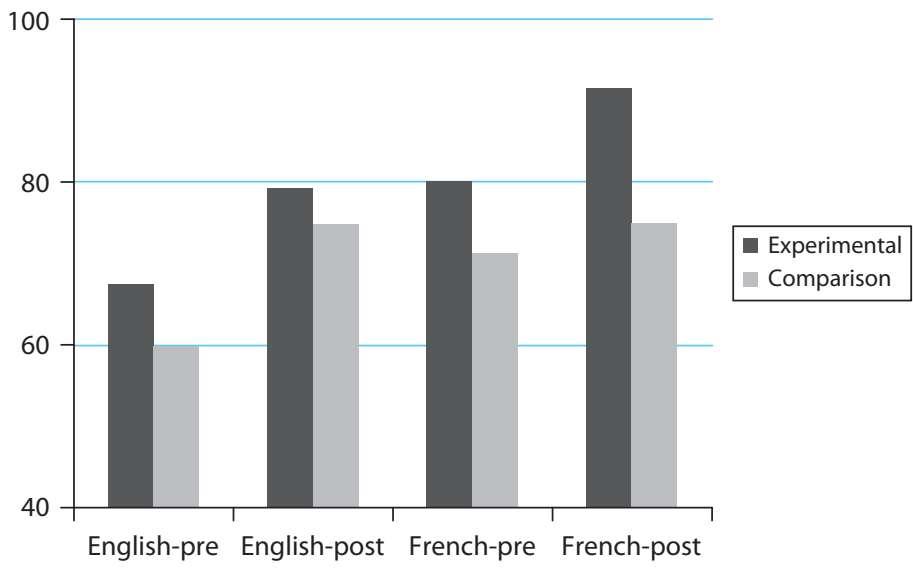

Figure 1. Pre- and post-test means by group on the MAT in English and French 
Table 2. Descriptive statistics and one-way ANCOVA results for the MAT by group

\begin{tabular}{|c|c|c|c|c|c|c|}
\hline & \multicolumn{3}{|c|}{ English Version } & \multicolumn{3}{|c|}{ French Version } \\
\hline & \multirow{2}{*}{$\frac{\text { Pretest }}{M(S D)}$} & \multicolumn{2}{|l|}{ Posttest } & \multirow{2}{*}{$\begin{array}{l}\text { Pretest } \\
M(S D)\end{array}$} & \multicolumn{2}{|l|}{ Posttest } \\
\hline & & $M(S D)$ & $\operatorname{adj} M(S E)$ & & $M(S D)$ & $\operatorname{adj} M(S E)$ \\
\hline Experimental & $\begin{array}{l}67.52 \\
(18.24)\end{array}$ & $\begin{array}{l}79.39 \\
(20.04)\end{array}$ & $\begin{array}{l}79.97 \\
(2.34)\end{array}$ & $\begin{array}{l}80.24 \\
(18.33)\end{array}$ & $\begin{array}{l}91.78 \\
(15.85)\end{array}$ & $\begin{array}{l}90.01 \\
(1.71)\end{array}$ \\
\hline Comparison & $\begin{array}{l}59.95 \\
(17.69)\end{array}$ & $\begin{array}{l}75.00 \\
(19.32)\end{array}$ & $\begin{array}{l}76.82 \\
(3.56)\end{array}$ & $\begin{array}{l}71.45 \\
(22.87)\end{array}$ & $\begin{array}{l}75.15 \\
(20.65)\end{array}$ & $\begin{array}{l}79.13 \\
(2.58)\end{array}$ \\
\hline
\end{tabular}

\subsubsection{Analysis by language dominance}

To investigate whether the instructional gains differed according to students' language dominance profiles, separate two-way ANCOVAs were conducted on the post-test scores of each version the MAT with two factors (group and language dominance) using pre-test scores as a covariate. The descriptive results are summarized in Table 3. As reported earlier, the pre-test scores obtained on the measures of receptive vocabulary size (i.e., the PPVT-4 and EVIP) were used to classify individual students as English-dominant $(n=17)$, French-dominant $(n=21)$, or bilingual $(n=27)$.

Table 3. Descriptive statistics and two-way ANCOVA results for each version of the MAT by group and language dominance

\begin{tabular}{|c|c|c|c|c|c|c|}
\hline & \multicolumn{3}{|c|}{ English Version } & \multicolumn{3}{|c|}{ French Version } \\
\hline & \multirow{2}{*}{$\frac{\text { Pretest }}{M(S D)}$} & \multicolumn{2}{|l|}{ Posttest } & \multirow{2}{*}{$\frac{\text { Pretest }}{M(S D)}$} & \multicolumn{2}{|l|}{ Posttest } \\
\hline & & $M(S D)$ & $\operatorname{adj} M(S E)$ & & $M(S D)$ & $\operatorname{adj} M(S E)$ \\
\hline \multicolumn{7}{|l|}{ Experimental } \\
\hline English-dominant & $\begin{array}{l}74.78 \\
(15.77)\end{array}$ & $\begin{array}{l}95.44 \\
(15.43)\end{array}$ & $\begin{array}{l}89.42 \\
(4.92)\end{array}$ & $\begin{array}{l}69.33 \\
(18.16)\end{array}$ & $\begin{array}{l}80.78 \\
(10.64)\end{array}$ & $\begin{array}{l}85.70 \\
(3.92)\end{array}$ \\
\hline French-dominant & $\begin{array}{l}58.40 \\
(15.72)\end{array}$ & $\begin{array}{l}68.33 \\
(18.33)\end{array}$ & $\begin{array}{l}72.56 \\
(3.80)\end{array}$ & $\begin{array}{l}84.25 \\
(14.41)\end{array}$ & $\begin{array}{l}93.62 \\
(13.60)\end{array}$ & $\begin{array}{l}89.60 \\
(2.95)\end{array}$ \\
\hline Bilingual & $\begin{array}{l}71.10 \\
(19.03)\end{array}$ & $\begin{array}{l}80.45 \\
(18.53)\end{array}$ & $\begin{array}{l}76.73 \\
(3.29)\end{array}$ & $\begin{array}{l}81.95 \\
(20.05)\end{array}$ & $\begin{array}{l}95.25 \\
(17.76)\end{array}$ & $\begin{array}{l}92.60 \\
(2.62)\end{array}$ \\
\hline \multicolumn{7}{|l|}{ Comparison } \\
\hline English-dominant & $\begin{array}{l}69.13 \\
(15.97)\end{array}$ & $\begin{array}{l}76.38 \\
(15.20)\end{array}$ & $\begin{array}{l}73.89 \\
(5.11)\end{array}$ & $\begin{array}{l}53.63 \\
(21.33)\end{array}$ & $\begin{array}{l}60.25 \\
(16.87)\end{array}$ & $\begin{array}{l}74.60 \\
(4.56)\end{array}$ \\
\hline French-dominant & $\begin{array}{l}42.40 \\
(13.05)\end{array}$ & $\begin{array}{l}58.60 \\
(17.39)\end{array}$ & $\begin{array}{l}72.84 \\
(6.94)\end{array}$ & $\begin{array}{l}82.20 \\
(14.72)\end{array}$ & $\begin{array}{l}80.80 \\
(18.21)\end{array}$ & $\begin{array}{l}78.00 \\
(5.19)\end{array}$ \\
\hline Bilingual & $\begin{array}{l}62.00 \\
(14.35)\end{array}$ & $\begin{array}{l}85.14 \\
(19.08)\end{array}$ & $\begin{array}{l}87.12 \\
(5.45)\end{array}$ & $\begin{array}{l}84.14 \\
(16.55)\end{array}$ & $\begin{array}{l}88.14 \\
(16.65)\end{array}$ & $\begin{array}{l}84.18 \\
(4.41)\end{array}$ \\
\hline
\end{tabular}


Results of the two-way ANCOVA on the English MAT post-test scores revealed a significant interaction between group and language dominance, $F(2$, $57)=3.78, p=0.029$, and a subsequent test of simple effects revealed a significant difference between experimental and comparison groups for English-dominant students, $F(1,57)=4.89, p=0.031$. With respect to the French MAT, the two-way ANCOVA confirmed the significant effect for group previously detected by the one-way analysis but revealed no significant interaction between group and language dominance, $F(2,58)=0.10, p=0.91$.

\subsubsection{Analysis by program type}

To investigate whether program type affected instructional effectiveness, two-way ANCOVAs were conducted on post-test scores of each version of the MAT as dependent variables with group and program type as independent variables. In the current study, students were associated with one of three programs distinguished by different proportions of instructional time in the target languages: (a) $80 \%$ French $+20 \%$ English $(n=24)$; (b) $50 \%$ French $+50 \%$ English $(n=21)$; (c) $20 \%$ French $+80 \%$ English $(n=20)$. Descriptive results are summarized in Table 4 .

On the English MAT, the two-way ANCOVA revealed no significant effects for either group or program type and no significant interaction between group and program type, $F(1,58)=0.80, p=0.37$. On the French MAT, the two-way ANCOVA confirmed the significant effect for group previously detected by the

Table 4. Descriptive statistics and two-way ANCOVA results for each version of the MAT by group and program type

\begin{tabular}{|c|c|c|c|c|c|c|}
\hline & \multicolumn{3}{|c|}{ English Version } & \multicolumn{3}{|c|}{ French Version } \\
\hline & \multirow{2}{*}{$\frac{\text { Pretest }}{M(S D)}$} & \multicolumn{2}{|l|}{ Posttest } & \multirow{2}{*}{$\frac{\text { Pretest }}{M(S D)}$} & \multicolumn{2}{|l|}{ Posttest } \\
\hline & & $M(S D)$ & $\operatorname{adj} M(S E)$ & & $M(S D)$ & $\operatorname{adj} M(S E)$ \\
\hline \multicolumn{7}{|c|}{ Experimental } \\
\hline $80 \%$ French & $\begin{array}{l}79.50 \\
(17.11)\end{array}$ & $\begin{array}{l}92.71 \\
(17.09)\end{array}$ & $\begin{array}{l}82.78 \\
(4.29)\end{array}$ & $\begin{array}{l}70.86 \\
(16.41)\end{array}$ & $\begin{array}{l}84.64 \\
(14.91)\end{array}$ & $\begin{array}{l}89.38 \\
(3.20)\end{array}$ \\
\hline $50 \%$ French & $\begin{array}{l}64.52 \\
(18.13)\end{array}$ & $\begin{array}{l}72.81 \\
(19.97)\end{array}$ & $\begin{array}{l}73.25 \\
(3.23)\end{array}$ & $\begin{array}{l}83.48 \\
(21.21)\end{array}$ & $\begin{array}{l}94.14 \\
(16.73)\end{array}$ & $\begin{array}{l}89.93 \\
(2.61)\end{array}$ \\
\hline 20\% French & $\begin{array}{l}55.89 \\
(7.96)\end{array}$ & $\begin{array}{l}74.00 \\
(15.15)\end{array}$ & $\begin{array}{l}80.42 \\
(5.05)\end{array}$ & $\begin{array}{l}86.60 \\
(6.63)\end{array}$ & $\begin{array}{l}96.80 \\
(12.82)\end{array}$ & $\begin{array}{l}90.38 \\
(3.80)\end{array}$ \\
\hline \multicolumn{7}{|l|}{ Comparison } \\
\hline $80 \%$ French & $\begin{array}{l}55.30 \\
(19.62)\end{array}$ & $\begin{array}{l}77.40 \\
(24.47)\end{array}$ & $\begin{array}{l}84.23 \\
(4.82)\end{array}$ & $\begin{array}{l}88.50 \\
(10.91)\end{array}$ & $\begin{array}{l}83.50 \\
(18.40)\end{array}$ & $\begin{array}{l}75.73 \\
(3.83)\end{array}$ \\
\hline 20\% French & $\begin{array}{l}64.60 \\
(15.09)\end{array}$ & $\begin{array}{l}72.60 \\
(13.28)\end{array}$ & $\begin{array}{l}72.99 \\
(4.69)\end{array}$ & $\begin{array}{l}54.40 \\
(18.42)\end{array}$ & $\begin{array}{l}66.80 \\
(20.15)\end{array}$ & $\begin{array}{l}83.20 \\
(4.25)\end{array}$ \\
\hline
\end{tabular}


one-way analysis but revealed no significant effect for program and no significant interaction between group and program type, $F(1,59)=0.59, p=0.45$.

\subsubsection{Summary of statistical results}

At the time of post-testing, the experimental group significantly outperformed the comparison group in French, but not in English, and these positive effects in French were similar for all students receiving the instruction irrespective of language dominance or program type. In English, although students receiving the instruction did not, as a group, outperform students not receiving the instruction, the instructional treatment proved to have a significant effect on MAT post-test scores in English in the case of students identified as English dominant. In addition, phonological awareness proved to have a significant effect on MAT post-test scores in English but not in French.

\subsection{Teachers' perceptions}

The teachers were impressed by their students' positive reactions to the biliteracy instruction, stating that students "loved it" and "enjoyed making connections between the two languages." They were convinced, even in the absence of test results, that the biliteracy instruction focusing on derivational morphology had been effective because, as one teacher put it, her students were commenting on word formation during other activities: “They would say, 'Oh look! A little word inside a big word!'”

One of the concerns had been whether using the same storybook in both languages would have a boredom effect or create confusion rather than coherence for the children. The teachers were unanimous in dispelling any concerns of confusion or boredom. As one teacher stated, "the kids responded well to the lessons, and they saw that they were intertwined, and they liked the reading of the English book and the French book." Teachers ranked Crictor as their favourite, followed by Moon Man. They found The Three Robbers harder to integrate thematically and one pair qualified it as "kind of dark for little kids" and were pleased that its use with their students had been optional.

All teachers commented on the merits of having time to collaborate and to benefit, at the same time, from guidance provided by colleagues and researchers alike to support their collaboration. Prior to the project, some partner teachers had already been collaborating to varying degrees, most notably the French teacher and English teacher in the 50/50 program. Others were new to cross-lingual collaboration, stating that collaboration at their schools more typically involved teachers within content areas at the same grade level rather than across languages. One of the English teachers remarked that, unlike the collaboration experienced in the TCILL project, her previous attempts at collaboration had involved "more 
superficial collaboration, like for example, 'Oh, I hear you're doing bugs in your class. OK, I'll do some bug stuff too"'

\section{Discussion}

The present study yielded positive effects for collaborative efforts to integrate cross-linguistic pedagogy with biliteracy instruction on students' morphological awareness. Although it was only in French that the experimental group significantly outperformed the comparison group, a more fine-tuned analysis that accounted for the effects of language dominance and program type on MAT scores in English revealed a significant difference between English-dominant students receiving the instruction and their counterparts not receiving the instruction. The corresponding analysis of the French results revealed that the benefits of the biliteracy instruction on morphological awareness in French were similar for all students irrespective of their language dominance or program type.

The operationalization of morphological awareness in the present study was restricted to sublexical and lexical features and yet, as Bowers et al. (2010) state, the ultimate goal of the instruction "is not for children to learn about morphemes" (p. 145). Because the present study did not assess outcomes at the supralexical level, the effects of instruction on higher-order literacy skills at the supralexical level remain speculative. Bowers et al. (2010) explain the anticipated developmental gains as follows:

Explicit morphological instruction will increase understanding about the oral and written features of morphology at the sublexical level that, in turn, will influence literacy skills at the lexical level (e.g., word reading, spelling, and vocabulary) and the supralexical level (e.g., reading comprehension). (p. 145)

The design of their meta-analysis allowed Bowers et al. to investigate the degree to which sublexical instruction transfers up to lexical and supralexical measures. They found medium to strong effects at the sublexical level and medium effects at the lexical level. They also found that experimental versus control effects were stronger for younger students and that morphological instruction was most effective when integrated with other literacy instruction. Their findings thus find further support in the results of the present study: Learners as young as 7-8 years old can increase their morphological awareness at sublexical and lexical levels (as demonstrated by performance on decomposition and derivation tasks, respectively) as a result of instruction integrating a linguistic focus on derivational morphology with a thematic focus on storybooks. These results will now be further discussed in terms of teacher collaboration, learner motivation, and language-specific outcomes. 


\subsection{Teacher collaboration}

Much of the research on teacher collaboration in language education has focused on collaboration between content and language specialists, bringing to the fore various challenges in this regard (e.g., Arkoudis, 2006; Creese, 2002, 2006; Short, 2002). The present study added a new perspective with its focus on collaboration specifically between teachers of different target languages.

The research team benefited from having piloted the professional development component of the project during Year 1, because it led to the participation of three teachers from Year 1 as lead teachers during Year 2 who provided their colleagues with invaluable guidance in terms of task design and moral support. In addition, based on comments made by participating teachers during Year 1, which comprised six half-day professional development sessions, there were five full-day sessions during Year 2. The longer sessions along with the mentorship of lead teachers contributed greatly to the collaborative process and likely to its positive outcomes in Year 2, lending support to the argument that the extent to which teachers are able to reap the benefits of professional development is commensurate with "institutional commitments to provide teachers with sufficient time and sustainable opportunities for peer coaching in the spirit of cross-disciplinary collaboration" (Lyster \& Ballinger, 2011, p. 286).

\subsection{Learner motivation}

An especially positive result of the present study, as reported by the teachers and captured on the video recordings, was the enthusiasm exhibited by the children during the instructional interventions. In the same vein, Bowers et al. (2010) reported that several of the authors of the studies included in their meta-analysis "commented on the enthusiasm children showed during morphological instruction" (p. 171). While acknowledging that measures of motivation were not actually used, Bowers et al. suggested that, "increased motivation and literacy skills may mutually support each other" (p.171). In this view, the enthusiasm of the young children in the present study, as they adopted an almost detective-like approach to morphological derivation, may well have contributed positively to the significant differences that emerged between experimental and comparison groups.

\subsection{Language-specific outcomes}

The benefits of the instructional treatment proved to be language-specific to the extent that, as a group, students receiving the instruction significantly outperformed students not receiving the instruction in French but not in English. 
In addition, when students' language dominance was accounted for in the analysis of the English measure, only students identified as English dominant scored significantly higher in the experimental group than their counterparts in the comparison group. Previous findings concerning the development of language-specific aspects of morphological awareness (Deacon et al. 2007; Kuo \& Anderson, 2006; Pasquarella et al., 2011) are thus further substantiated by the present study.

Results of the one-way ANCOVA revealed a significant effect for phonological awareness on MAT post-test scores in English but not in French, and this may explain to some extent the language-specific outcomes showing greater treatment effects in French than in English. That is, because affixes in English entail less phonological neutrality than those in French, derivational morphology may be considered less transparent in English than in French and thus more difficult to learn. Neutral affixes are those having no phonological effect on the base to which they are attached. Examples from our morphological awareness measures include mouth $\Rightarrow$ mouthful or fool $\Rightarrow$ foolish in English and feuille $\Rightarrow$ feuillage or cloche $\Rightarrow$ clochette in French. In contrast, non-neutral affixes are those that result in a phonological shift affecting either the segmental or suprasegmental structure of the base. One third of the items on the English version of the MAT in the present study entailed a phonological shift (e.g., continue $\Rightarrow$ continuity; electric $\Rightarrow$ electricity; major $\Rightarrow$ majority; national $\Rightarrow$ nationality; stupid $\Rightarrow$ stupidity) whereas all items in French were phonologically neutral (e.g., montagne $\Rightarrow$ montagneux; pauvre $\Rightarrow$ pauvreté), thereby reflecting the greater phonological neutrality (and orthographic transparency) of French relative to English.

The effect of phonological neutrality on performance of morphological tasks is considered especially apparent with younger children (Kuo \& Anderson, 2006) and so may help to explain why the young children in the present study made greater progress in French than in English. The finding that only Englishdominant students made significant progress on the English MAT points to the likelihood that they already had intuitive knowledge of non-neutral affixes, resulting from their greater exposure to phonological shifts, which in turn supported their performance in oral tasks requiring production of a derived form with a non-neutral suffix. Worthy of further pursuit in this regard is whether the preponderance of phonologically non-neutral affixes in English relative to French influences the crossover effects of biliteracy instruction targeting derivational morphology.

Another possible explanation for the significant progress in French but not English may be related to the delivery of the instruction in each language. That is, one might conjecture more emphasis on metalinguistic awareness in French language instruction, given its emphasis on structural analysis, than in English language instruction, given its emphasis on language development though whole 
language approaches that take precedence over language analysis. The French teachers with training in mother tongue education may have been more accustomed to a metalinguistic focus in their teaching than the English teachers with training in English language arts; as a result, the students themselves may have been primed for a stronger metalinguistic focus in French than in English. However, this is purely speculative and did not arise as an issue during the workshops or in any of the qualitative data. If there was such a disparity between partner teachers, it can be said to have contributed to a positive synergy and complementarity during the collaborative process.

\section{Limitations}

The design of the present study has many limitations that restrict our ability to isolate specific aspects of the instruction or other intervening variables that may have affected the outcomes. The TCILL project emphasized professional development and teacher collaboration while its focus on learner outcomes was considered secondary. The instructional treatments were thus not completely identical from one classroom to the next insofar as the teachers, although they had all participated in the same set of five professional development workshops, were encouraged to draw on their own creativity in co-designing biliteracy tasks. Moreover, there was considerable variability in the student sample, thus limiting the comparability within and across groups. While we benefitted from conducting research in such a linguistically rich and diverse school board, its constituent municipalities were manifestly variable in terms of exposure to French and English both inside and outside of schools.

Given the statistical design of the present study, a much larger sample would have been preferred, especially in the comparison group. In terms of measures, the use of the French and English versions of the Peabody receptive vocabulary tests to determine language dominance seemed innovative within the scope of this project but one that clearly requires further investigation and refinement. Finally, the biliteracy instruction focusing on derivational morphology lends itself well to English and French because they are closely related and share many cognates. The outcomes of the present study do not allow for speculation about the effectiveness of biliteracy instruction targeting non-cognate languages, although the study's collaborative design could serve as a model for teachers to integrate a thematic or content-based focus across languages rather than a linguistic one. 


\section{Conclusion}

The present study yielded positive effects for biliteracy instruction co-designed by partner teachers on their students' morphological awareness at sublexical and lexical levels. The experimental group significantly outperformed the comparison group in French and the effects were similar for all students regardless of their language dominance or program type. The experimental group did not outperform the comparison group in English, but when students' language dominance was accounted for in this measure, English-dominant students were shown to perform significantly better in the experimental group than in the comparison group. The finding that only English-dominant students showed significant benefits in English from the biliteracy instruction may reflect their greater exposure to phonological shifts in English suffixation. However, further investigation is needed to explore other possible causes for the language-specific outcomes of biliteracy instruction focusing on derivational morphology in both French and English.

This study brought together complementary areas of the educational literature advocating an instructional focus on morphological awareness for literacy development and, more specifically, on cross-lingual connections for bilteracy development. In addition to this educational focus, the study contributes to the instructed L2 acquisition literature by adding a professional development component to research on form-focused instruction for the purpose of strengthening educational practice while addressing theoretically motivated questions. Finally, the study's overall positive results underscore the benefits of a university and school board partnering to engage teachers in professional development with opportunities for peer coaching and collaborative planning.

\section{Acknowledgements}

This study was supported by a grant from the Quebec Ministère de l'Éducation, du Loisir et du Sport (MELS) through its Program to Support the Professional Development of School Staff. We gratefully acknowledge Riverside School Board for partnering with us and extend our gratitude to its administrative staff and to all the principals, teachers, and students who welcomed us into the participating schools. We thank José Correa for conducting the analyses of covariance and also express our thanks to Kazuya Saito and three anonymous reviewers for helpful comments on earlier versions of this article. Earlier versions of this study were presented in 2012 as plenary talks by the first author at the 20th National Two-Way Immersion Conference in Newport Beach, the 11th International Conference of the Association for Language Awareness in Montreal, and the 4th International Conference on Immersion Education in Minneapolis. 


\section{References}

Allen, P., Swain, M., Harley, B., \& Cummins, J. (1990). Aspects of classroom treatment: Toward a more comprehensive view of second language education. In B. Harley, P. Allen, J. Cummins, \& M. Swain (Eds.), The development of second language proficiency (pp. 57-81). Cambridge, UK: Cambridge University Press.

Arkoudis, S. (2006). Negotiating the rough ground between ESL and mainstream teachers. International Journal of Bilingual Education and Bilingualism, 9, 415-433.

Bauer, L., \& Nation, I.S.P. (1993). Word families. International Journal of Lexicography, 6, 1-27.

Bowers, P.N., \& Kirby, J.R. (2010). Effects of morphological instruction on vocabulary acquisition. Reading and Writing: An Interdisciplinary Journal, 23, 515-537.

Bowers, P., Kirby, J., \& Deacon, H. (2010). The effects of morphological instruction on literacy skills: A systematic review of the literature. Review of Educational Research, 80, 144-179.

British National Corpus. (2001). [data file]. Available from University of Oxford at http://www. natcorp.ox.ac.uk/

Cameron, L. (2001). Teaching languages to young learners. Cambridge, UK: Cambridge University Press.

Carlisle, J. (2000). Awareness of the structure and meaning of morphologically complex words: Impact on reading. Reading and Writing: An Interdisciplinary Journal, 12, 169-190.

Carlisle, J. (1995). Morphological awareness and early reading achievement. In L.B. Feldman (Ed.), Morphological aspects of language processing (pp. 189-209). Hillsdale, NJ: Erlbaum.

Casalis, S., \& Louis-Alexandre, M.-F. (2000). Morphological analysis, phonological analysis and learning to read French: A longitudinal study. Reading and Writing: An Interdisciplinary Journal, 12, 303-335.

Cenoz, J., \& Gorter, D. (2011). Focus on multilingualism: A study of trilingual writing. The Modern Language Journal, 95, 356-369.

Clipperton, R. (1994). Explicit vocabulary instruction in French immersion. The Canadian Modern Language Review, 50, 737-749.

Cobb, T. (n.d.). The compleat lexical tutor [computer software]. Retrieved from http://www. lextutor.ca/

Cobb, T., \& Horst, M. (2004). Is there room for an AWL in French? In P. Bogaards \& B. Laufer (Eds.), Vocabulary in a second language: Selection, acquisition, and testing (pp.15-38). Amsterdam: John Benjamins.

Cook, V. (2001). Using the first language in the classroom. The Canadian Modern Language Review, 57, 402-423.

Cormier, P., Grandmaison, É., MacDonald, G.W., \& Ouellette-Lebel, D. (1995). Développement d'un test d'analyse auditive en français: normes et validation de construit. [Development of an Auditory Analysis Test in French: standardization and construct validation]. Revue des sciences de l'éducation, 21, 223-240.

Coxhead, A. (2000). A new academic word list. TESOL Quarterly, 34, 213-238.

Coxhead, A. (1998). An academic word list [ELI Occasional Publication Number 18]. Wellington, NZ: School of Linguistics and Applied Language Studies, Victoria University of Wellington.

Creese, A. (2002). The discursive construction of power in teacher partnerships: Language and subject specialists in mainstream schools. TESOL Quarterly, 36, 597-616.

Creese, A. (2006). Supporting talk? Partnership teachers in classroom interaction. International Journal of Bilingual Education and Bilingualism, 9, 434-453. 
Cummins, J. (2007). Rethinking monolingual instructional strategies in multilingual classrooms. Canadian Journal of Applied Linguistics, 10, 221-241.

Deacon, H., Wade-Woolley, L., \& Kirby, J. (2007). Crossover: The role of morphological awareness in French immersion children's reading. Developmental Psychology, 3, 732-746.

Dubois, J. (1962). Étude sur la dérivation suffixale en français moderne et contemporain. [A study of suffix derivation in modern contemporary French]. Paris: Larousse.

Dunn, L., \& Dunn, D. (2007). Peabody Picture Vocabulary Test, Fourth Edition (PPVT $\left.{ }^{\text {Tom}}-4\right)$. San Antonio, TX: Pearson Education.

Dunn, L., Dunn, L., \& Thériault-Whalen, C. (1993). Échelle de vocabulaire en images Peabody. Toronto, ON: Pearson Canada Assessment.

Gougenheim, G. (1958). Dictionnaire fondamental de la langue française. Paris: Didier.

Harley, B. (1992). Patterns of second language development in French immersion. Journal of French Language Studies, 2, 159-183.

Harley, B., \& King, M. (1989). Verb lexis in the written compositions of young L2 learners. Studies in Second Language Acquisition, 11, 415-439.

Harley, B., \& Jean, G. (1999). Vocabulary skills of French immersion students in their second language. Zeitschrift für Interkulturellen Fremdsprachenunterricht, 4(2). Retrieved from http://zif.spz.tu-darmstadt.de/jg-04-2/beitrag/harley2.htm

Hobbs, J., \& Nasso-Maselli, M. (2005). Elementary programs study. St. Lambert, QC: Riverside School Board.

Kuo, L.-J., \& Anderson, R.C. (2006). Morphological awareness and learning to read: A crosslanguage perspective. Educational Psychologist, 41, 161-180.

Laufer, B. (2003). Vocabulary acquisition in a second language: Do learners really acquire most vocabulary by reading? Some empirical evidence. The Canadian Modern Language Review, $59,567-588$.

Lyster, R. (2007). Learning and teaching languages through content: A counterbalanced approach. Amsterdam: John Benjamins.

Lyster, R., \& Ballinger, S. (2011). Content-based language teaching: Convergent concerns across divergent contexts. Language Teaching Research, 15, 279-288.

Lyster, R., Collins, L., \& Ballinger, S. (2009). Linking languages through a bilingual read-aloud project. Language Awareness, 18, 366-383.

McBride-Chang, C., Wagner, R., Muse, A., Chow, B., \& Shu, H. (2005). The role of morphological awareness in children's vocabulary acquisition in English. Applied Psycholinguistics, 26, $415-435$.

Pasquarella, A., Chen, X., Lam, K., \& Luo, Y. (2011). Cross-language transfer of morphological awareness in Chinese-English bilinguals. Journal of Research in Reading, 34, 23-42.

Nation, P. (2001). Learning vocabulary in another language. Cambridge: Cambridge University Press.

Quiroga, J. (2013). Measuring morphological awareness across languages. Unpublished master's thesis, McGill University, Montreal, Canada.

Retman, R. (1980). Un inventaire des suffixes adjectivaux du français contemporain. [An inventory of adjectival suffixes in contemporary French]. Le français moderne, 48, 6-15.

Rosner, J., \& Simon, D. (1971). The auditory analysis test: An initial report. Journal of Learning Disabilities, 4, 384-392.

Short, D. (2002). Language learning in sheltered social studies classes. TESOL Journal, 11, 18-24.

Schmitt, N. (2008). State of the art: Instructed second language vocabulary acquisition. Language Teaching Research, 12, 329-363. 
Soltero-González, L., Escamilla, K., \& Hopewell, S. (2012). Changing teachers' perceptions about the writing abilities of emerging bilingual students: Towards a holistic bilingual perspective on writing assessment. International Journal of Bilingual Education and Bilingualism, 15, 71-94.

Swain, M., \& Lapkin, S. (2013). A Vygotskian sociocultural perspective on immersion education: The L1/L2 debate. Journal of Immersion and Content-Based Education, 1, 101-129.

Ungerer, T. (1958). Crictor. New York: Harper Collins.

Ungerer, T. (1962/2008). The three robbers. New York: Phaidon.

Ungerer, T. (1967/2009). Moon man. New York: Phaidon.

Vander, G. (1932). French word book. New York: Macmillan.

Webb, S. (2005). Receptive and productive vocabulary learning: The effects of reading and writing on word knowledge. Studies in Second Language Acquisition, 27, 33-52.

West, M. (1953). A general service list of English words. London: Longman, Green \& Co.

\section{Appendix A - Decomposition Items on Section 1 of Morphological Awareness Test}

\section{English version}

1. honourable

2. mouthful

3. foolish

4. unhappiness

5. hopefulness

6. sensible

7. detectable

8. assistance

9. misinterpretation

10. uncomfortable

11. continuity

12. dissatisfy

13. departure

14. nationality

15. naturalist

16. ${ }^{\star}$ famous

17. ${ }^{\star}$ decision

18. * originality

19. ${ }^{\star}$ reduction

20. ${ }^{\star}$ reliable

\section{French version}

1. montagneux

2. héroïque

3. amical

4. incontrôlable

5. malheureusement

6. feuillage

7. prisonnier

8. sauveur

9. découragement

10. sentimentalisme

11. lainage

12. suivant

13. éducation

14. individualisme

15. décongélation

16. * gagnant

17. ${ }^{\star}$ clochette

18. *blanchâtre

19. *relire

20. * soutenir

${ }^{\star}$ Asterisked items in English are from Carlisle (2000) and those in French are from Casalis and Louis-Alexandre (2000) 


\section{Appendix B - Derivation Items on Section 2 of Morphological Awareness Test}

\section{English version}

1. When your friends help you, they are very: [helpful]

2. If you work on a farm, you are a: [farmer]

3. If you bake a cake, you probably are a: [baker]

4. If you are good at making friends, people say you are: [friendly]

5. My grandparents arrive today; we are waiting for their: [arrival]

6. If somebody does something stupid, he shows his: [stupidity]

7. I plug in my electric toaster because it needs: [electricity]

8. The opposite of respect is: [disrespect]

9. If your classmates present in class, they are doing a: [presentation]

10. When a person is not honest, he is: [dishonest]

11. When we are aware of how to use water, we have environmental: [awareness]

12. Resources that come from nature are called: [natural]

13. When you obey your parents, you are showing your: [obedience]

14. When you fly for many hours, you have a long: [flight]

15. Things that destroy our nature are very: [destructive]

16. ${ }^{*}$ Profit. Selling lemonade in summer is: [profitable]

17. ${ }^{\star}$ Protect. She wore glasses for: [protection]

18. * Major. He won the vote by a: [majority]

19. ${ }^{*}$ Absorb. She chose the sponge for its: [absorption]

20. ${ }^{\star}$ Humour. The story was quite: [humorous]

${ }^{*}$ Asterisked items are from Carlisle (2000).

\section{French version}

1. Celui qui danse est un: [danseur]

2. Ce lion présente un danger, donc il est: [dangereux]

3. Un pays qui a beaucoup de montagnes est un pays: [montagneux]

4. Celui qui voyage est un: [voyageur]

5. Celui qui joue de la guitare est un: [guitariste]

6. Le boulanger travaille dans une: [boulangerie]

7. Quand je me brûle, j'ai une: [brûlure]

8. Une personne qui n'est pas honnête est une personne: [malhonnête]

9. Ce qui est profond a de la: [profondeur]

10. Le contraire de sensible c'est: [insensible]

11. Celui qui est pauvre vit dans la: [pauvreté]

12. Cet homme est riche. Il a une grande: [richesse]

13. Si je suis bien éduqué, j’ai une bonne: [éducation]

14. Le territoire du roi est son: [royaume]

15. Un arbre qui a beaucoup de feuilles a un grand: [feuillage]

16. ${ }^{*}$ Celui qui ment est un: [ment] 
17. ${ }^{*}$ Celui qui punit donne des: [punition]

18. ${ }^{*}$ Le contraire de coller, c'est: [décoller]

19. ${ }^{\star}$ Un enfant qui n'est pas bien élevé est: [mal élevé]

20. ${ }^{\star}$ Mettre autour c'est: [entourer]

${ }^{*}$ Asterisked items are from Casalis and Louis-Alexandre (2000)

\title{
Résumé
}

Cette étude d'une intervention en classe visait à analyser les incidences d'un enseignement en situation de bilitéracie sur la conscience morphologique en français et en anglais chez des élèves de 2e année. Trois paires d'enseignants partenaires (français/anglais) participant à un projet de perfectionnement professionnel ont conçu et mis en œuvre un programme d'enseignement en situation de bilitéracie auprès de leurs 80 élèves dont la langue dominante était l'anglais ou le français, ou qui étaient bilingues (français/anglais). L'enseignement centrait l'attention linguistique sur la morphologie dérivationnelle à partir de la lecture de livres de contes illustrés. Avant et après l'intervention, nous avons procédé à des mesures séparées de la conscience morphologique en français et en anglais d'un sous-groupe de leurs élèves $(n=45)$ de même que d'un groupe témoin $(n=20)$ à qui l'enseignement expérimental n'était pas donné. Le groupe expérimental a fait nettement mieux que le groupe témoin en français alors qu'en anglais seulement les élèves du groupe expérimental dont la langue dominante était l'anglais ont eu des résultats supérieurs à ceux de leurs paires du groupe témoin.

\section{Authors' addresses}

\author{
Roy Lyster \\ Department of Integrated Studies in \\ Education \\ Susan Ballinger \\ McGill University \\ McGill University \\ 3700 McTavish \\ 3700 McTavish Street \\ Montreal, QC H3A 1Y2 \\ Canada \\ Montreal, QC H3A 1Y2 \\ Canada \\ susan.ballinger@mail.mcgill.ca \\ roy.lyster@mcgill.ca \\ Jorge Quiroga \\ McGill University \\ 3700 McTavish \\ Montreal, QC H3A 1Y2 \\ Canada \\ jorge.quiroga@mail.mcgill.ca
}

